\title{
Landscape perception based on personal attributes in determining the scenic beauty of in-stand natural secondary forests
}

\author{
Y. Chen, B. Sun, S.B. Liao, L. Chen, S.X. Luo
}

Chen Y., Sun B., Liao S.B., Chen L., Luo S.X., 2016. Landscape perception based on personal attributes in determining the scenic beauty of in-stand natural secondary forests. Ann. For. Res. 59(1): 91-103.

\begin{abstract}
The aim of this paper was to validate factors affecting the in-stand landscape quality and how important each factor was in determining scenic beauty of natural secondary forests. The study was limited to 23 stand-level cases of natural secondary forests in Shen Zhen city in southern China. Typical samples of photographs and public estimations were applied to evaluate scenic beauty inside the natural secondary forests. The major factors were then selected by multiple linear-regression analysis and a model between scenic beauty estimation (SBE) values and in-stand landscape features was established. Rise in crown density, fall in plant litter, glow in color of trunk, fall in arbor richness, and rise in visible distance increased scenic beauty values of in-stand landscape. These five factors significantly explained the differences in scenic beauty, and together accounted for $45 \%$ of total variance in SBEs. Personal factors (e.g. gender, age and education) did not significantly affect the ratings of landscape photos, although variations of landscape quality were affected by some personal factors. Results of this study will assist policymakers, silviculturists and planners in landscape design and management of natural secondary forests in Shenzhen city. People can improve the scenic beauty values by pruning branches and clearing plant litter, which subsequently improve the forest health and contribute to forest recreation. Keywords forest aesthetics, forest structure, scenic beauty estimation, aesthetic assessment, personal factors
\end{abstract}

Authors. Yong Chen (gzforest@126.com), Bing Sun, Shaobo Liao, Lei Chen, Shuixing Luo - Research Institute of Tropical Forestry, Chinese Academy of Forestry, 682 Guangshan $1^{\text {st }}$ Road, Guangzhou Guangdong, 510520 China.

Manuscript received March 16, 2015; revised June 30, 2015; accepted August 24, 2015; online first September 14, 2015.

\section{Introduction}

Scenic beauty is an important and indispensa- ble natural resource to human (Denker 2004) and as such the aesthetic value of landscape is often taken into account in forest planning de- 
cisions (Ribe 2009). The scenic beauty is not only scientific, but also of public and political taste (Council of Europe 2000, Wascher 2000). Scenic beauty of a landscape is judged from opinion of observer in response to the landscape (Daniel \& Boster 1976, Daniel 2001). In-stand forest scenes are fallen across when the observer is in the forest, as opposed to observing the forest from a distance (Brown \& Daniel 1986). Forest has a positive influence on stress relief and psychological and physiological health (Tzoulas et al. 2007, van den Berg et al. 2007, Niemelä et al. 2010, Tyrväinen et al. 2014). The requirement for outdoor activity has been rising constantly (Raitz \& Dakhil 1988) because of scenic beauty, wildlife, fresh air, and forests (Beza 2010). In addition, the mountain view can increase the property value (Franklin \& Waddell 2003).

The aesthetic assessment of landscape has made considerable progresses in recent years. There are two methods about aesthetic assessment, the objectivist and the subjectivist methods (Lothian 1999). The objective or physical paradigms are some intrinsic landscape properties, and the subjective or psychological paradigms are what root of the eyes of the observers. The subjectivist method of aesthetics has been adopted by most researchers in recent centuries. Photos are taken in order to determine the landscape quality of rural, water, forest, wetland and farmland in the field. The photography is a very fast way of determining the work, and the cost of the work is reduced (García Moruno et al. 2006, Cañas et al. 2009, Zubelzu \& del Campo 2014).

Ecosystem services are considered in planning and management of resources and forest (MEA 2005). Ecosystems have many consequences for human well-being through the services they provide through, for example, totemic species, sacred groves, trees, scenic landscapes, geological formations, or rivers and lakes. These attributes and functions of ecosystems influence the aesthetic, recreational, educational, and cultural aspects of people. Some authors considered that personal factors, 92 such as experience, education, age and cultural background, were important in determining scenic beauty (Kaplan \& Kaplan 1989, Ribe 2002, Kearney et al. 2008). However, others such as Gruehn \& Roth (2010), Roth (2012) and Frank et al. (2013) concluded that personal factors did not significantly affect the SBE values. Furthermore, Cañas et al. (2009) found that students, neighbourhood residents, and university hall residents had no significant differences in scenic beauty values. Therefore, planners, analysts, silviculturists and geographers need to understand the scenic beauty estimations (SBE) (Ribe 2009, Pâtru-Stupariu et al. 2010). In China, landscape quality estimation was studied by Lu et al. (1985) in Zijin Mountain in 1960s, and the research has become one of the hottest research topics since 1990s with the development of forest recreation in the country.

The European Landscape Convention classifies landscape into five types: degraded landscape, everyday landscape (common), good quality landscape, high quality landscape, and outstanding landscapes (ELC 2000). However, Chen and Wang (2001) concluded that forest landscapes should be divided into seven types, viz., detail landscape, individual landscape, instand landscape, forest-lined road landscape, foreground landscape, mid-ground landscape, and far-away landscape. Parameters for various landscape attributes have been studied, but it is difficult to decide which attributes affect landscape perception and how important each attribute is in deciding the whole landscape quality (Williams et al. 2007). Natural landscapes (i.e. water body and forest) contributed more to aesthetic values than semi-natural and human-dominated landscapes (Yang et al. 2014). Visual features are affected not only by natural factors, but also by the configuration, especially by the diversity and richness, and by the color, form and spatial structure (De la Fuente De Val et al. 2006, Tveit et al. 2006). Chen \& Jia (2003) found that form and arrangement of tree trunks, dead trees and fallen woods, coverage and uniformity of undergrowth, and 
degree of slope were the main factors affecting the quality of in-stand landscapes in the mountain area of West Beijing, China. In terms of uniformity of undergrowth, regular undergrowth adds aesthetic value (Chen \& Jia 2003, Yan et al. 2009). Silvennoinen et al. (2002) and Bradley et al. (2004) found that thinning could increase moderate scenic beauty, while Brown \& Daniel (1986), Ribe (2009), Li et al. (2011) concluded that increased scenic beauty could be expected with larger trees.

In China, researchers found that the main factors which affected the in-stand landscape quality were not so identical because of different study areas, diverse types of vegetations, and different study methods. However, they tended to share a same view that stand density and coverage of undergrowth were the main factors affecting the scenic beauty of instand forest (Chen \& Jia 2003, Zhang 2003, Wang \& Luo 2004, Gu et al. 2008, Yan et al. 2009 ). Most of the studies about forest landscape quality were taken place in northern and eastern China, and there have been very few reports of study in southern China. We have therefore chosen natural secondary forests in Shenzhen city in the southern most of mainland China as the research site. The objectives of this study were (1) to determine the effects of forest landscape attributes on in-stand scenic beauty of natural secondary forests, (2) to investigate the influence of personal factors (i.e. gender, age and education) on the scenic beauty estimation (SBE) and (3) to find out how to adjust the forest structure and improve the in-stand landscape quality.

\section{Materials and methods}

\section{Study area}

The study area, Shenzhen City, Guangdong province, China, is situated between $22^{\circ} 27^{\prime} \mathrm{N}$ and $22^{\circ} 52^{\prime} \mathrm{N}$ latitude and between $113^{\circ} 46^{\prime} \mathrm{E}$ and $114^{\circ} 37^{\prime} \mathrm{E}$ longitude, and has a total area of $1991.64 \mathrm{~km}^{2}$ (Chen et al. 2013). With tropical monsoon climate, the mean annual temperature, mean annual precipitation and sunshine hours from 1990 to 2011 are $23.2^{\circ} \mathrm{C}, 1905 \mathrm{~mm}$ and $1848 \mathrm{~h}$, respectively. The main types of soil are latosol, paddy soil, seashore sandy soil and saline soil. The dominant vegetation types are evergreen broad-leaved mixed forest, garden plots, cropland and pastureland (Chen et al. 2013).

\section{Forest sample}

The study was limited to 23 stand-level cases of natural secondary forests at Shenzhen Yangtaishan Forest Park, Shenzhen Wutongshan National Park, Shenzhen Paiyashan Nature Reserve, Xiao Meisha Fung Shui woodlands, and Meilin Reservoir (see Fig. 1). The crown density, aspect, degree of slope, altitude, longitude and latitude of these sites were described in Table 1. Average crown density was 0.8 . Average density was 3646 stems per hectare. Richness of arbor averaged 9.7. Visible distance averaged $23 \mathrm{~m}$. Arbor diameter at breast height averaged $10.6 \mathrm{~cm}$. Arbor tree height averaged $6.7 \mathrm{~m}$. Arbor height to the first branch averaged $2 \mathrm{~m}$. Coverage of undergrowth averaged $57.7 \%$. Height of undergrowth averaged $0.6 \mathrm{~m}$. Degree of slope averaged $19.3^{\circ}$. The stand means, standard deviations and variables of these sites are described in Table 2.

\section{Surveying stand structure}

Measurements of stand structure were taken in 2012 with quadrate 0.12 -ha plots $(30 \mathrm{~m} \times 40$ $\mathrm{m})$. Crown density, species, diameter at breast height (dbh), tree height, height under first branch, the number of dead trees, coverage of undergrowth, bark color, form of trunk, uniformity of undergrowth, height of undergrowth, visible distance, and degree of slope were assessed.

Crown density was measured within each plot by taking measurements at 5 evenly spaced points (Ganey \& Block 1994). Tree height for all trees $>1.5 \mathrm{~m}$ was registered by species, and 


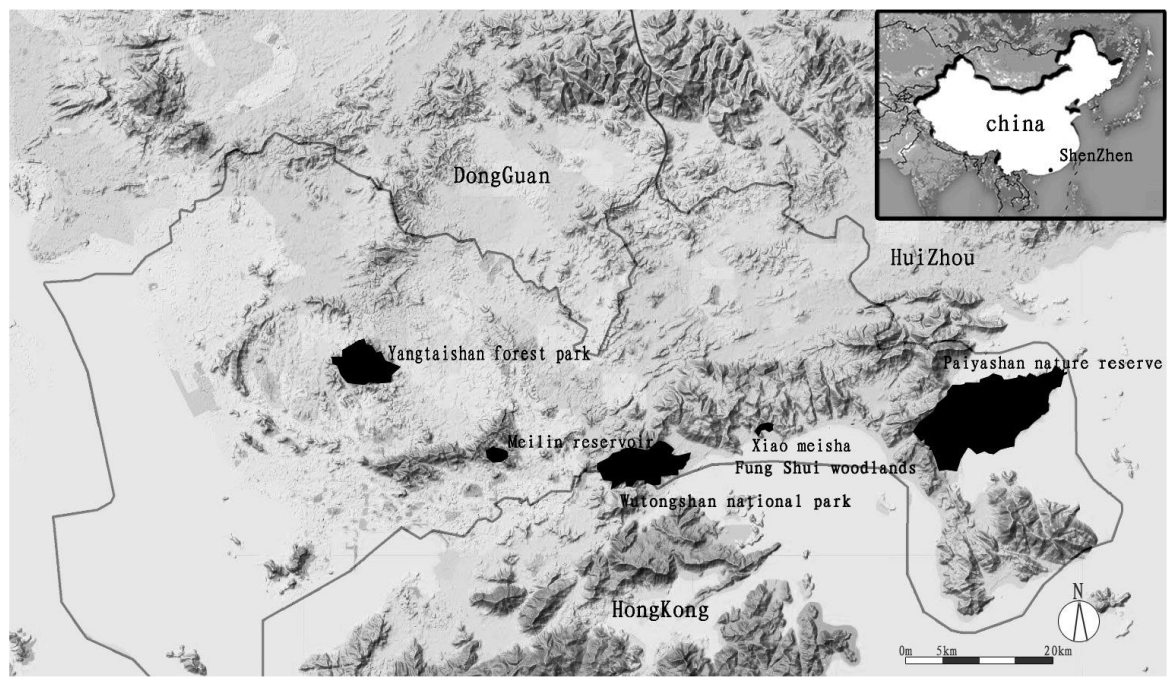

Figure 1 Locations of five forest parks in Shenzhen city where the study was conducted

marked as live or dead. Diameter was measured at $1.3 \mathrm{~m}$ above the ground with a diameter tape to the nearest $0.1 \mathrm{~mm}$. Height to the first branch was measured to the nearest 0.1 $\mathrm{m}$. The dead trees were tallied. Uniformity of undergrowth was estimated visually by eye.

Undergrowth was recorded for 3 species groups: grasses, forbs, and shrubs (Brown \& Daniel 1986). Height of undergrowth was measured to the nearest $0.1 \mathrm{~m}$. The degree of slope was measured by using a DQL-5 compass. Bark color and form of trunk were assessed visually by eye.

\section{Field photography}

To guarantee repeatability of the study, all photographs were taken according to the following principles. (1) All photographs were taken between 9:00 a.m. and 4:00 p.m., when the sun was high enough to supply sufficient light and did not cause overfull shadows. (2) All photographs were taken in 23 different plots using a digital single lens reflex camera with $24 \mathrm{~mm}$ lens and with the aid of a tripod standing at the height of $1.6 \mathrm{~m}$. (3) The photographs did not include people, wildlife, roads and rocks because they could affect the scenic quality. (4) A range pattern of eight points was applied for photo plot near all the edges. Eight pictures were taken at the eight points in their orientations toward the middle of the plots (Ribe 2009). Finally, 44 pictures which were distinct, typical and no defend offend were picked out to make the lantern slides.

\section{Observers}

Landscape estimations were carried out by 92 observers who had landscape, forestry or botany background. Their personal data such as gender, age and education level were recorded. The age range was 19-57 years with an average of 30.8. Both male and female participated, of which 47 (51\%) were male and 45 (49\%) were female. They were divided into three groups of about 30 each.

\section{Estimating scenic beauty}

The lantern slides taken at each sample point were shown to groups of respondents who rated them on a 7 -point scale $(-3$ to +3$) ;-3$ indicated "very low scenic beauty" and +3 indicat- 
Table 1 Information on selected variables for in-stand landscape in Shenzhen city

\begin{tabular}{|c|c|c|c|c|c|c|}
\hline No. & Sites & $\begin{array}{l}\text { Crown } \\
\text { density }\end{array}$ & Aspect & $\begin{array}{l}\text { Slope } \\
\left({ }^{\circ}\right)\end{array}$ & $\begin{array}{l}\text { Altitude } \\
(\mathrm{m})\end{array}$ & Latitude/Longitude \\
\hline 1 & Yangtaishan forest park & 0.90 & ES & 30 & 120 & 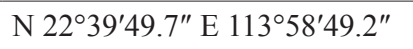 \\
\hline 2 & Yangtaishan forest Park & 0.80 & $\mathrm{~W}$ & 28 & 440 & 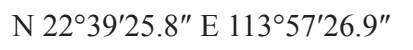 \\
\hline 3 & Yangtaishan forest park & 0.80 & $\mathrm{E}$ & 18 & 372 & $\mathrm{~N} 22^{\circ} 39^{\prime} 02.2^{\prime \prime}$ E $113^{\circ} 57^{\prime} 22.8^{\prime \prime}$ \\
\hline 4 & Yangtaishan forest Park & 0.90 & $\mathrm{WN}$ & 25 & 490 & $\mathrm{~N} 22^{\circ} 39^{\prime} 17.5^{\prime \prime}$ E $113^{\circ} 57^{\prime} 37.3^{\prime \prime}$ \\
\hline 5 & Yangtaishan forest park & 0.80 & $\mathrm{~N}$ & 40 & 196 & 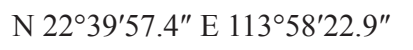 \\
\hline 6 & Yangtaishan forest Park & 0.85 & $\mathrm{E}$ & 21 & 230 & $\mathrm{~N} 22^{\circ} 40^{\prime} 03.7^{\prime \prime}$ E $113^{\circ} 58^{\prime} 18.9^{\prime \prime}$ \\
\hline 7 & Yangtaishan forest park & 0.75 & $\mathrm{~S}$ & 28 & 210 & $\mathrm{~N} 22^{\circ} 40^{\prime} 16.6^{\prime \prime} \mathrm{E} 113^{\circ} 57^{\prime} 43.5^{\prime \prime}$ \\
\hline 8 & Yangtaishan forest Park & 0.80 & $\mathrm{~S}$ & 30 & 283 & N 223'의 $46.6^{\prime \prime}$ E $113^{\circ} 57^{\prime} 08.8^{\prime \prime}$ \\
\hline 9 & Yangtaishan forest park & 0.70 & $\mathrm{E}$ & 27 & 135 & $\mathrm{~N} 22^{\circ} 38^{\prime} 15.2^{\prime \prime}$ E $113^{\circ} 58^{\prime} 12.8^{\prime \prime}$ \\
\hline 10 & Yangtaishan forest Park & 0.75 & WN & 35 & 367 & $\mathrm{~N} 22^{\circ} 38^{\prime} 50.25^{\prime \prime} \mathrm{E} 113^{\circ} 57^{\prime} 54.6^{\prime \prime}$ \\
\hline 11 & Yangtaishan forest park & 0.75 & $\mathrm{~W}$ & 24 & 120 & $\mathrm{~N} 22^{\circ} 38^{\prime} 05.9^{\prime \prime} \mathrm{E} 113^{\circ} 58^{\prime} 25.3^{\prime \prime}$ \\
\hline 12 & Yangtaishan forest Park & 0.80 & ES & 12 & 390 & $\mathrm{~N} 22^{\circ} 38^{\prime} 55.3^{\prime \prime} \mathrm{E} 113^{\circ} 57^{\prime} 53.8^{\prime \prime}$ \\
\hline 13 & Wutongshan national park & 0.80 & $\mathrm{WN}$ & 30 & 119 & N 22³5'28.4" E $114^{\circ} 11^{\prime} 51.7^{\prime \prime}$ \\
\hline 14 & Wutongshan national park & 0.80 & $\mathrm{WN}$ & 10 & 90 & $\mathrm{~N} 22^{\circ} 35^{\prime} 30.6^{\prime \prime} \mathrm{E} 114^{\circ} 11^{\prime} 53.2^{\prime \prime}$ \\
\hline 15 & Wutongshan national park & 0.75 & $\mathrm{~N}$ & 20 & 666 & $\mathrm{~N} 22^{\circ} 34^{\prime} 06.0^{\prime \prime}$ E $114^{\circ} 12^{\prime} 05.3^{\prime \prime}$ \\
\hline 16 & Wutongshan national park & 0.80 & $\mathrm{~W}$ & 20 & 580 & $\mathrm{~N} 22^{\circ} 34^{\prime} 23.7^{\prime \prime}$ E $114^{\circ} 12^{\prime} 31.4^{\prime \prime}$ \\
\hline 17 & $\begin{array}{l}\text { Xiao meisha Fung } \\
\text { Shui woodlands }\end{array}$ & 0.75 & $\mathrm{~S}$ & 8 & 33 & $\mathrm{~N} 22^{\circ} 36^{\prime} 14.2^{\prime \prime} \mathrm{E} 114^{\circ} 19^{\prime} 21.6^{\prime \prime}$ \\
\hline 18 & $\begin{array}{l}\text { Xiao meisha Fung } \\
\text { Shui woodlands }\end{array}$ & 0.75 & $\mathrm{~S}$ & 10 & 36 & $\mathrm{~N} 22^{\circ} 36^{\prime} 14.0^{\prime \prime}$ E $114^{\circ} 19^{\prime} 21.9^{\prime \prime}$ \\
\hline 19 & $\begin{array}{l}\text { Xiao meisha Fung } \\
\text { Shui woodlands }\end{array}$ & 0.75 & $\mathrm{~S}$ & 10 & 30 & $\mathrm{~N} 22^{\circ} 36^{\prime} 19.7^{\prime \prime}$ E $114^{\circ} 19^{\prime} 21.0^{\prime \prime}$ \\
\hline 20 & Paiyashan nature reserve & 0.70 & W & 10 & 280 & 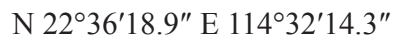 \\
\hline 21 & Paiyashan nature reserve & 0.70 & $\mathrm{~W}$ & 10 & 30 & $\mathrm{~N} 22^{\circ} 36^{\prime} 36.0^{\prime \prime} \mathrm{E} 114^{\circ} 32^{\prime} 28.8^{\prime \prime}$ \\
\hline 22 & Paiyashan nature reserve & 0.80 & $\mathrm{~W}$ & 12 & 170 & $\mathrm{~N} 22^{\circ} 36^{\prime} 56.2^{\prime \prime}$ E $114^{\circ} 32^{\prime} 23.5^{\prime \prime}$ \\
\hline 23 & Meilin reservoir & 0.90 & $\mathrm{~S}$ & 18 & 82 & N 22³4'11.3" E $114^{\circ} 01^{\prime} 49.3^{\prime \prime}$ \\
\hline
\end{tabular}

ed "very high scenic beauty". Each slide rating session began with the reading of standardized instructions and presentation of preview slides which depicted the range of slides to be rated subsequently. The rated slides were exposed at random for 8 seconds and the respondents recorded a judgment on a sense-mark sheet. The second part of the questionnaires included personal background, e.g. gender, age and education. The three rating sessions were held separately at the South China Agricultural University and Research Institute of Tropical Forestry, Chinese Academy of Forestry in Guangzhou.

\section{Statistical analyses}

Individual ratings were transformed to standard $(z)$ scores by the following formula (Chen \& Jia 2003):

$Z_{\bar{j}}=\left(R_{j}-\overline{R_{j}}\right) / S_{j}$

where: $Z_{i j}$ - standardized $(z)$ score for the $i^{\text {th }}$ rating response of observer $j, R_{i j}-i^{\text {th }}$ rating of observer $j, \overline{R_{j}}$ - mean of all ratings by observer $j$, $S_{j}$ - standard deviation of all ratings by observer $j$. Analysis of variance was performed using SPSS 19.0. Multivariate linear regression was 
Table 2 Information on selected variables for in-stand landscape in Shenzhen city

\begin{tabular}{|c|c|c|c|c|c|}
\hline \multicolumn{2}{|l|}{ Variable } & \multirow{2}{*}{ Mean } & \multirow{2}{*}{$\mathrm{SD}^{\mathrm{a}}$} & \multicolumn{2}{|c|}{ Range } \\
\hline Description & Name & & & Min. & Max. \\
\hline Scenic beauty estimate & SBE & -0.2 & 0.4 & -1.2 & 0.6 \\
\hline Bark color $^{\mathrm{b}}$ & $\mathrm{CT}$ & 1.4 & 0.8 & 1.0 & 4.0 \\
\hline Major color ${ }^{\mathrm{c}}$ & $\mathrm{MC}$ & 1.2 & 0.4 & 1.0 & 2.0 \\
\hline Richness of color ${ }^{\mathrm{d}}$ & $\mathrm{RC}$ & 2.0 & 0.2 & 1.0 & 2.0 \\
\hline Litter $^{\mathrm{e}}$ & LI & 1.8 & 0.7 & 1.0 & 3.0 \\
\hline Dead trees or fallen woods ${ }^{\mathrm{f}}$ & DW & 2.5 & 0.8 & 1.0 & 3.0 \\
\hline Form of trunks ${ }^{\mathrm{g}}$ & FT & 2.2 & 0.6 & 1.0 & 3.0 \\
\hline Proportion of dominant species $(\%)^{\mathrm{h}}$ & PDS & 2.7 & 0.6 & 1.0 & 3.0 \\
\hline Interlayer plant ${ }^{\mathrm{i}}$ & IP & 1.7 & 0.8 & 1.0 & 3.0 \\
\hline Uniformity of undergrowth ${ }^{\mathrm{j}}$ & UU & 2.4 & 0.7 & 1.0 & 3.0 \\
\hline $\operatorname{Ages}(\mathrm{yr})^{\mathrm{k}}$ & AG & 2.5 & 1.0 & 1.0 & 5.0 \\
\hline Attainability $^{1}$ & AT & 2.1 & 0.7 & 1.0 & 3.0 \\
\hline Health condition ${ }^{\mathrm{m}}$ & $\mathrm{HC}$ & 1.1 & 0.4 & 1.0 & 3.0 \\
\hline Status of growing ${ }^{\mathrm{n}}$ & SG & 1.0 & 0.1 & 1.0 & 2.0 \\
\hline Crown density & $\mathrm{CD}$ & 0.8 & 0.1 & 0.5 & 0.9 \\
\hline Density (no./ha) & $\mathrm{DE}$ & 3645.8 & 2153.9 & 550.0 & 9300.0 \\
\hline Richness of arbor (no.) & RA & 9.7 & 4.4 & 2.0 & 20.0 \\
\hline Arbor mean dbh $(\mathrm{cm})$ & AMD & 10.6 & 8.1 & 3.5 & 35.0 \\
\hline Arbor mean tree height $(\mathrm{m})$ & AMH & 6.7 & 3.4 & 3.2 & 15.0 \\
\hline Arbor mean height under first branch (m) & AMHB & 2.0 & 1.0 & 0.7 & 6.0 \\
\hline Proportion of trunk and branch (\%) & PTB & 28.1 & 9.5 & 10.0 & 56.7 \\
\hline Coverage of undergrowth (\%) & $\mathrm{CU}$ & 57.7 & 24.2 & 20.0 & 100.0 \\
\hline Visible distance $(\mathrm{m})$ & VD & 23.0 & 6.2 & 10.0 & 35.0 \\
\hline Height of undergrowth (m) & HU & 0.6 & 0.2 & 0.3 & 1.1 \\
\hline Degree of slope $\left(^{\circ}\right)$ & DS & 19.3 & 8.0 & 5.0 & 40.0 \\
\hline
\end{tabular}

Note. Superscript significance: a - standard deviation; b - an ordinal variable, where 1 - color of trunks is grey, 2 - brown, 3 - white, 4 - yellow, 5 - green; c - an ordinal variable, where 1 - major color is green, 2 -g rey; $\mathrm{d}$ - an ordinal variable, where 1 - richness of color is abundance, 2 - ordinary, 3 - singularity; e - an ordinal variable, where 1 - litter is striking, 2 - commonly, 3 - few; f - an ordinal variable, where 1 - dead trees or fallen woods is striking, 2 - commonly, 3 - few; g - an ordinal variable, where 1 - form of trunks is straight, 2 - ordinary, 3 - crooked; h - an ordinal variable, where 1 - dominant tree species is over $80 \%, 2-50 \%-80 \%, 3-<50 \%$; i - an ordinal variable, where 1 - interlayer plant is abundance, 2 - commonly, 3 - few; j - an ordinal variable, where 1 - uniformity of undergrowth is unified, 2 - comparatively unified, 3 - not unified; $\mathrm{k}$ - an ordinal variable, where 1 - trees are overmature forest, 2 - mature forest, 3 - near-mature forest, 4 - middle-aged forest, 5 - young forest; 1 - an ordinal variable, where 1 - attainability of stands is high, 2 - ordinary, 3 - low; $\mathrm{m}$ - an ordinal variable, where 1 - health condition is healthy, 2 - subhealthy, 3 - sickness; $\mathrm{n}$ - an ordinal variable, where 1 - status of growing is Flourishing, 2 - common, 3 - poor.

used to build the model for explaining variance in SBE values.

\section{Results}

\section{Assessing the impacts of the major land- scape variables to scenic beauty}

The major factors affecting SBE values were crown density, plant litter, colour of trunk, 
richness of arbor, and visible distance; and these were listed by the B values (Table 3). All five factors significantly explained differences in scenic beauty, and together explained $45 \%$ of total variance in SBEs. The tolerances were over 0.5 , and VIFs were less then 5 , so the regression model was valid.

Because the linear correlation between the five factors and SBEs was prominent (Table 4, $F=8.059, P<0.001)$ the linear models could be established.

The histogram of regression standardized residual basically obey normal distribution (Fig. 2). All spots were basically laid in a relatively straight line, and the hypothesis which obey the normal distribution was correct (Fig. 3). The variation range of regression standardized residual remained stable, and the residual variance was equal (Fig. 4).

On the whole, the major variables were crown density, plant litter, colour of trunk, richness of arbor, and visible distance in the natural secondary forests, and the model was accurate. Increased scenic beauty of the natural secondary forests could be expected with rise in crown density, fall in litter, fall in richness of arbor, raise in visible distance, and glow in color of trunk.

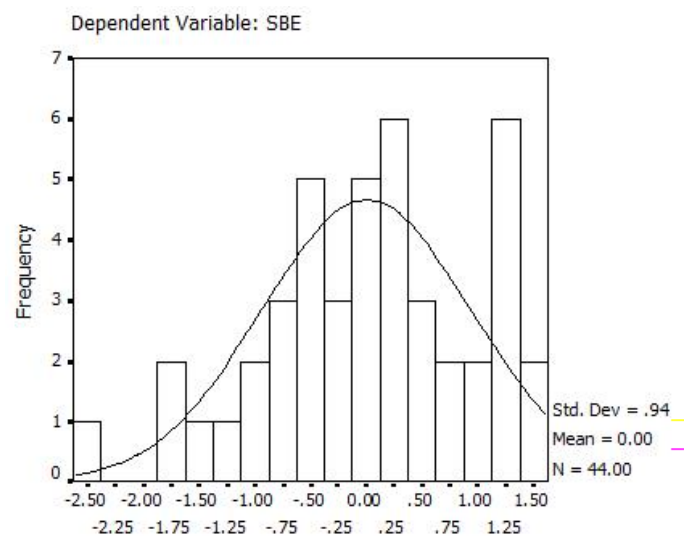

Figure 2 Histogram of regression standardized residual

\section{Analyzing the influence of personal factors in scenic beauty estimation}

The first personal factor analyzed was the personal qualification. The histograms show that the ratings of their variability for undergraduates, postgraduates, and experts were similar. The Kruskal-Wallis-Test revealed that the asymptotic significance $(P=0.572)$ was greater than 0.05 , so there were no significant differences in the SBE values of undergraduates, postgraduates and experts (Fig. 5).

The individuals were divided into three age groups, less than 30 years old, 30-40 years old, and more than 40 years old. The Kruskal-Wallis-Test revealed that the asymptotic significance $(\mathrm{P}=0.328)$ was greater than 0.05 , so the second personal factor, i.e. age, did not affect the SBE values significantly. The ratings of three age groups were congruent, and only slight divergences were found (Fig. 6).

The third personal factor analyzed was gender. Average SBE values for the 44 pictures of 23 sites are presented in the histograms (Fig. 7). The analysis indicated statistically significant differences among pictuers. There was a clear trend in the SBE values between women and men, and slight divergences (only no. 4, 18, 30 and 43) were found (Fig. 7).

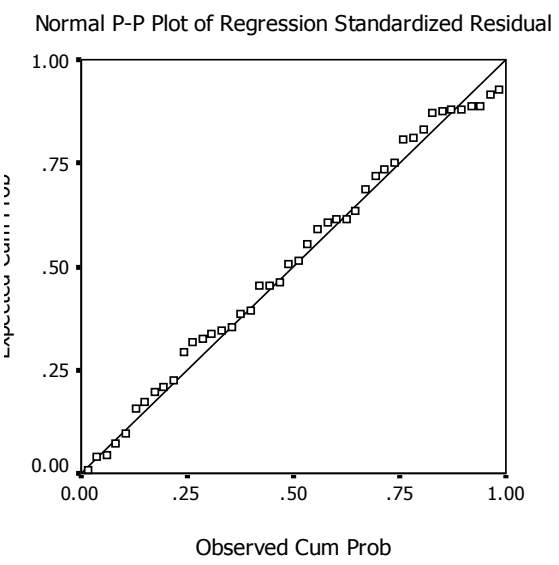

Figure 3 Cumulative probability plot 
Table 3 Analysis of model coefficients of in-stand landscape in Shenzhen's natural secondary forest

\begin{tabular}{lrrrrrrr}
\hline \multirow{2}{*}{\begin{tabular}{c} 
Model \\
\multicolumn{1}{c}{20}
\end{tabular}} & \multicolumn{2}{c}{$\begin{array}{c}\text { Unstandardized } \\
\text { coefficients }\end{array}$} & $\begin{array}{c}\text { Standardized } \\
\text { coefficients }\end{array}$ & $T$ & P-value & \multicolumn{2}{c}{$\begin{array}{c}\text { Collinearity } \\
\text { statistics }\end{array}$} \\
\cline { 2 - 3 } & \multicolumn{1}{c}{ Beta } & Std. Error & Beta & & & Tolerance & VIF \\
\hline Constant & -2.016 & 0.596 & & -3.384 & 0.002 & & \\
Bark color $\mathrm{X}_{1}$ & 0.157 & 0.060 & 0.296 & 2.593 & 0.013 & 0.984 & 1.017 \\
Litter $\mathrm{X}_{4}$ & 0.215 & 0.079 & 0.366 & 2.719 & 0.010 & 0.706 & 1.416 \\
Crown density $\mathrm{X}_{16}$ & 1.753 & 0.703 & 0.371 & 2.494 & 0.017 & 0.578 & 1.730 \\
Richness of arbor $\mathrm{X}_{18}$ & -0.063 & 0.013 & -0.689 & -4.863 & 0.000 & 0.636 & 1.573 \\
Visible distance $\mathrm{X}_{24}$ & 0.021 & 0.008 & 0.325 & 2.511 & 0.016 & 0.764 & 1.309 \\
\hline Model & $R$ & $R^{2}$ & Adjusted $R^{2}$ & $F$-test & Prob. & & \\
20 & 0.717 & 0.515 & 0.451 & 8.059 & $<0.001$ & & \\
\hline
\end{tabular}

Table 4 Anova of in-stand landscape in Shenzhen's natural secondary forest

\begin{tabular}{llllll}
\hline Model & & $D F$ & Mean Squares & $F$ & Significance \\
\hline 20 & Regression & 5 & 0.719 & 8.059 & $2.94 \times 10^{-5}$ \\
& Residual & 38 & 0.089 & & \\
& Total & 43 & & & \\
& & & & \\
\hline
\end{tabular}

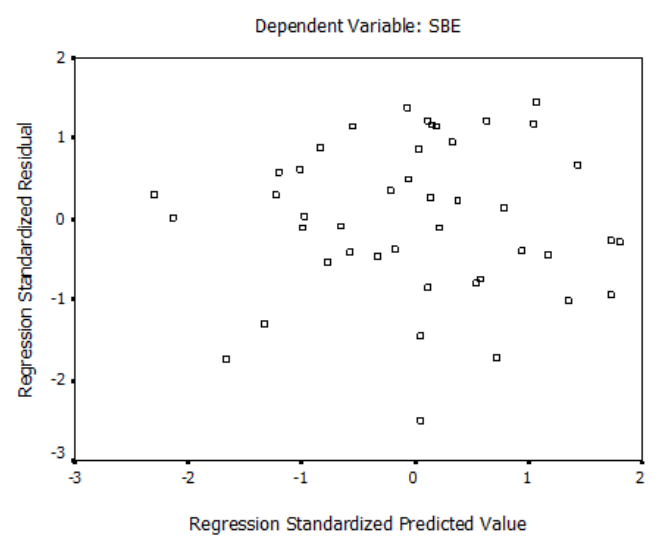

Figure 4 Scatter diagram between regression standardized predicted value and regression standardized residual

A Mann-Whitney U-test revealed that the asymptotic significance $(P=0.927)$ was greater than 0.05 , so there were no significant differences in the SBE values of women and men did not affect the values significantly.

\section{Discussion}

\section{The impacts of the major landscape variables} to scenic beauty

In the natural secondary forests in Shenzhen city, greater crown density, less litter, more richness of arbor, further visual distance and light color of trunk were found to contribute to aesthetic improvements. In the study, the plant litter is an important factor for the in-stand landscape quality. Results are similar to the conclusion of previous studies that less litter would contribute to aesthetic improvements (Vodak et al. 1985, Arthur 1977, Brown \& Daniel 1986, Wang \& Luo 2004).

The results indicated that scenic beauty was not correlated with form of trunks, which is similar to the view of Huan (2012). However, the surveys which indicated that in-stand scenic beauty with straight trunks was better, and that with crooked trunks was worse, were supported by Chen and Jia (2003), Wang and Luo (2004), Gu et al. (2008), Yan et al. (2009) and Yang et al. (2012). 


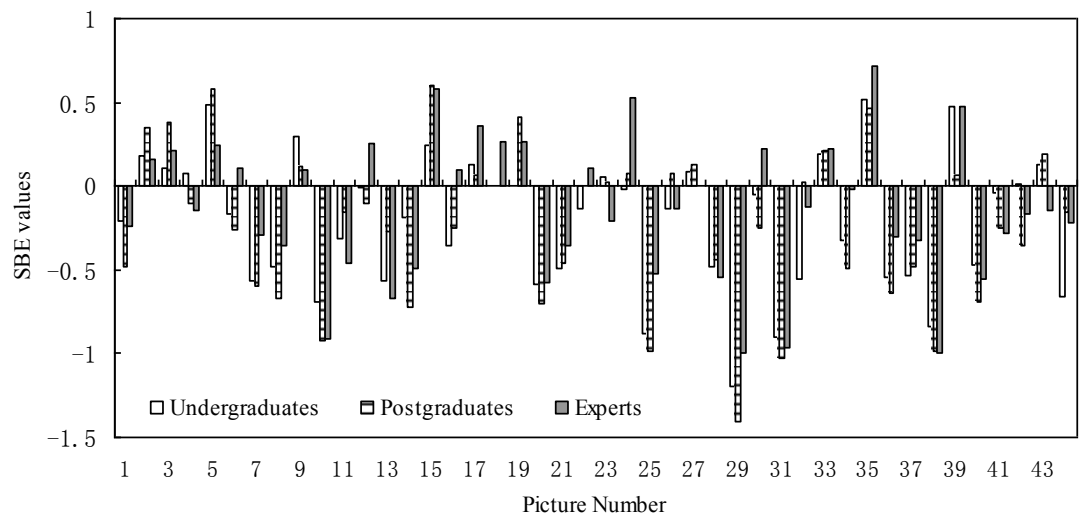

Figure 5 Histograms of the assessments by the observers according to the observers' professional qualification

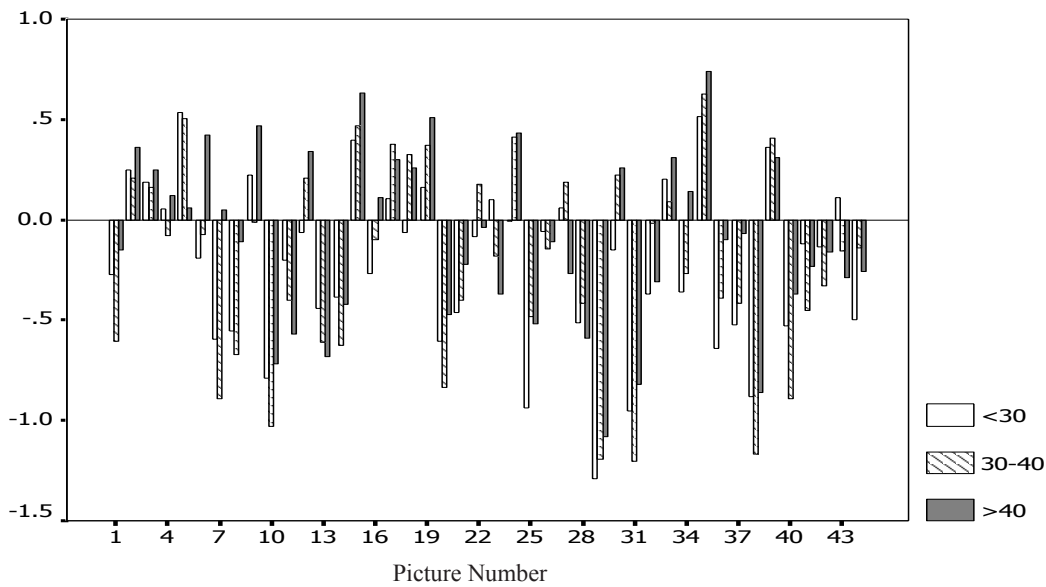

Figure 6 Histograms of the assessments by the observers according to the observers' age

The scenic beauty estimation (SBE) method has been applied to predict scenic beauty. Landscape values represented by digital videos, color slides or pictures are rated using a 10 -point rating scale, and a multivariate linear regression model is constructed to explain the variance in SBE values (Daniel \& Boster 1976). The method has been corroborated by abundant experimentation with planner, user and professional groups (Daniel \& Boster 1976, Brown \& Daniel 1986, Ribe 2009), but it had some shortcomings such as the immaturity of research methodology, insufficient understanding of the composition of forest beauty, and improper selection of forecast factors. In this study, with the rise in crown density, the SBE values would improve, which is similar to the view of Jia (2012). It appears that the greater crown density increases the mystery of natural secondary forests, and most people prefer them. However, Zhang (2007) concluded that the crown density did not affect the scenic beauty significantly, while Hull and Buhyoff (1986), Wang and Luo (2004), Gu et al. (2008) and Deng (2010) found that crown density was negatively related to the SBE values. The reasons maybe due to different forest types in different studies. 


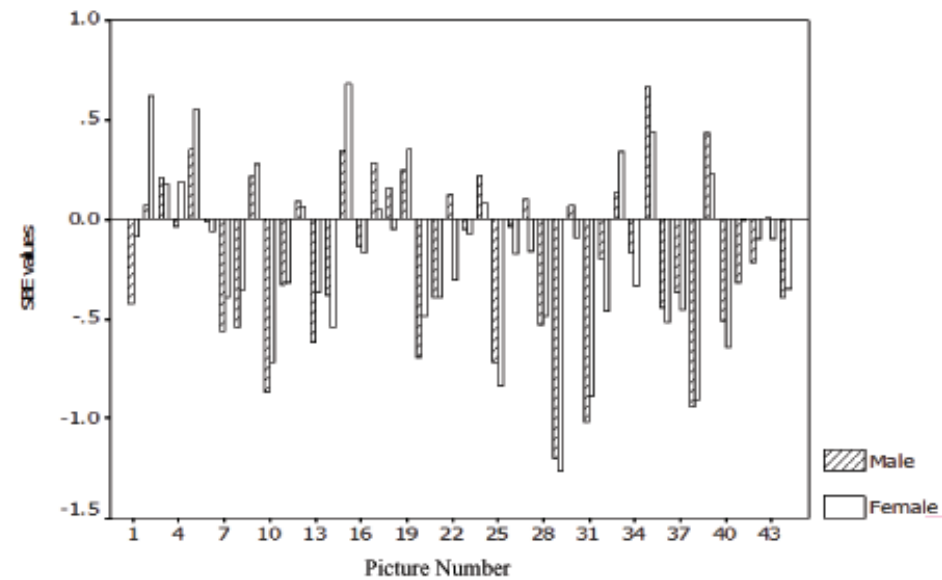

Figure 7 Histograms of the assessments by the observers according to the observers' gender

Further visual distance is helpful to improve the scenic beauty values of the stands in the study, which is similar to the view of Deng (2010). Yang et al. (2012) also found that further visual distance contributed to aesthetic improvements. In general, more dead trees or fallen woods, taller undergrowth, and greater slope would decrease the visual distance, People feel cramped or have depressive feelings, and develop a less favorable attitude.

Our results indicated that dead trees and fallen wood had no impact on in-stand landscape quality, which is contrary to those obtained by Arthur (1977), Vodak et al. (1985), Brown \& Daniel (1986) and Chen \& Jia (2003) who thought that dead trees and fallen woods may be problematic in impacting scenic beauty. While Rudis et al. (1988) found that a limited number of fallen woods could improve forest scenic beauty.

\section{Influence of personal factors on SBE values}

Almost all observers responded similarly in the forest landscape quality. Personal factors - gender, age and education - did not affect the ratings of landscape photos significantly, which is similar to previous scientific results (Green \& Tunstall 1992, Marylise 2013, Frank et al. 2013), but we found that some variations were affected by some personal factors. Fig. 8 (a) was in-stand forest landscape of Adina pilulifera + Psychotria asiatica community, the average height was about $3.8 \mathrm{~m}$, the plant litter was more, and the visual distance was short. Fig. 8 (b) was in-stand forest landscape of Machilus chinensis + Sarcosperma laurinum + Cinnamomum camphora community, the tree age was older, about 50-100 years old, the mean height was about $20 \mathrm{~m}$, the visual distance was long, and the species were rich. Fig. 8 (a) (SBE values $=0.58$ ) was found to be "very ugly" by most of the observers, but it was found to be "very beautiful" by others. Similarly, most of the observers found Fig. 8 (b) (SBE values = -1.16) "beautiful" or "very beautiful", but others found it "very ugly". Fig. 8 (b) obtained a better estimation than Fig. 8 (a) probably due to older age, longer visual distance and less plant litter.

\section{Conclusions}

This research has some important methodological and visual forest management implications. The major factors affecting in-stand SBE values of natural secondary forests were crown 
density, plant litter, colour of trunk, richness of arbor and visible distance. People can increase the visual distance by pruning branches and clearing plant litter, which subsequently improve the scenic beauty values and forest health, and contribute to forest recreation.

\section{Acknowledgments}

This study was supported by the Chinese government "11th Five-Year Plan" to Support Science and Technology Project, "Study on the construction technology of ecological landscape forest in suburb" (grant no. 2006BAD03A0602). We thank all participants in the perception survey. Valuable assistance was provided by Han Xu, Yuanchao Chen, Dongwei Liu, Gang Cai, Pengzhen Du, Haijun Wang, Meiting Wang and Bo Rong. We also owe special thanks to Khongsak Pinyopusarerk for his useful advice on English language revisions.

\section{References}

Arthur L.M., 1977. Predicting scenic beauty of forest environments: Some empirical tests. Forest Science 23(2): 151-160.

Beza B.B., 2010. The aesthetic value of a mountain landscape: A study of the MT. Everest Trek. Landscape and Urban Planning 97: 306-317. DOI: 10.1016/j.landurbp lan.2010.07.003

Bradley G.A., Kearney A.R., Wager J.A., 2004. Public reactions research. In: Curtis, R.O., Marshall, D.D., D.S. DeBell (eds.). Silvicultural Options for Young Growth Douglas-fir Forests: The Capitol Forest Study-establishment and first results. General Technical Report PNW598. USDA Forest Service, Portland, OR, pp. 63-73.

Brown T.C., Daniel T.C., 1986. Predicting scenic beauty of timber stands. Forest Science 32(2): 471-487.

Ca-as I., Ayuga E., Ayuga F., 2009. A contribution to the assessment of scenic quality of landscapes based on preferences expressed by the public. Land Use Policy 26: 1173-1181. DOI: 10.1016/j.landusepol.2009.02.007

Chen X. F., Wang Y., 2001. An analytic study on forest beauty-mostly on form beauty of forest plants. Scientia Silvae Sinicae 37(2): 122-130.

Chen X. F., Jia L. M., 2003. Research on evaluation of inforest landscape in west Beijing mountain area. Scientia Silvae Sinicae 39(4): 59-66.

Chen Y., Sun B., Liao S.B., Luo S.X., Liu D.W., Du P.Z., Li F.D., 2013. Classification of main phytocommunity and biodiversity in Shenzhen. Forest Research 26(5): 636-642.

Council of Europe, 2000. European Landscape Convention. Web: http://conventions.coe.int/Treaty/en/Treaties/Html/176.htmFlorence. Accessed: 02.2015.

Daniel, T.C., Boster R.S., 1976. Measuring landscape esthetics: the scenic beauty estimation method. USDA Forest service research paper RM-167, 66 p. Rocky mountain forest and range experiment station, Fort Collins, Colo.

Daniel T.C., 2001. Whither scenic beauty? Visual landscape quality assessment in the 21 st century. Landscape and Urban Planning 54: 267-281. DOI: 10.1016/S01692046(01)00141-4

De la Fuente De Val G., Atauri J.A., Lucio J.V. De., 2006. Relationship between landscape visual attributes and spatial pattern indices: a test study in Mediterraneanclimate landscapes. Landscape and Urban Planning 77:
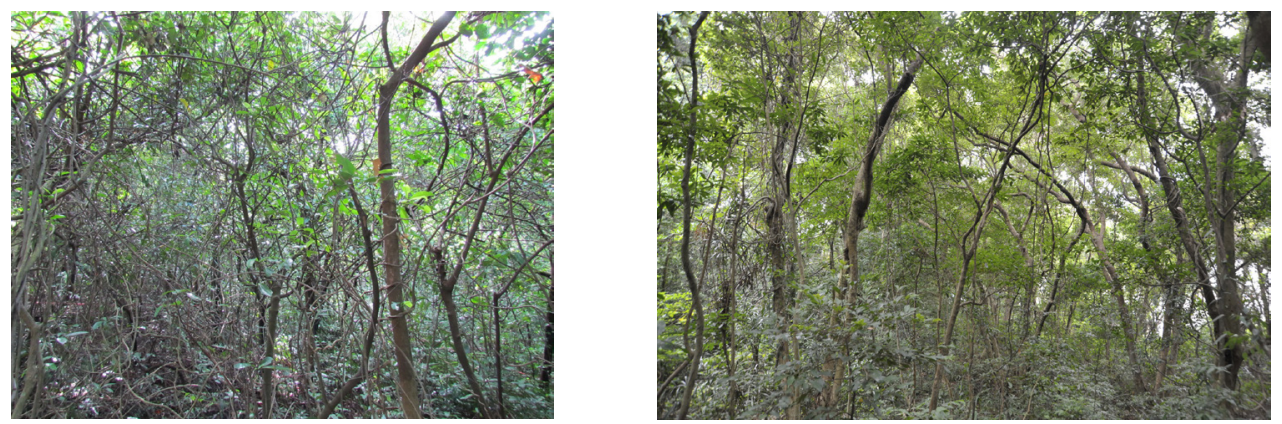

Figure 8 (Left) In-stand forest landscape of Adina pilulifera + Psychotria asiatica community; (Right) In-stand forest landscape of Machilus chinensis + Sarcosperma laurinum + Cinnamomum camphora community 
393-407.DOI: 10.1016/j.landurbplan.2005. 05.003

Deng S.Q., Yan J.F., Wang Y., Guan Q.W., 2010. Effects of thinning intensity on scenic beauty values of different types of stands. Journal of North East Forestry University 38(3): 4-7.

Denker C., 2004. The impact of aesthetic imagination on our ethical approach towards nature. Postgraduate Journal of Aesthetics 1(2): 51-58.

European Landscape Convention. Web: http://conventions.coe.int/Treaty/Commun/QueVoulezVous. asp?NT $=176 \& C M=8 \& C L=E N G$. Accessed: 02.2015 .

Frank S., Fürst C., Koschke L., Witt A., Makeschin F., 2013. Assessment of landscape aesthetics-Validation of a landscape metrics-based assessment by visual estimation of the scenic beauty. Ecological Indicators 32: 222231. DOI. org/10.1016/j.ecolind.2013.03.026

Franklin J.P., Waddell P., 2003. A hedonic regression of home prices in King County, Washington, using activity-specific accessibility measures. In: US Transportation Research Board of the National Academies Annual Meeting, Washington, DC, January, pp. 12-16.

Ganey J.L., Block W.M., 1994. A comparison of two techniques for measuring canopy closure. Western Journal of Applied Forestry 9: 21-23.

García M. L., Hernández B. J., Ayuga F., 2006. Analysis of the materials and exterior texture of agro-industrial buildings: a photo-analytical approach to landscape integration. Landscape and Urban Planning 74 (2): 110124. DOI: 10.1016/j.landurbplan.2004.10.007

Green C.H., Tunstall S.M., 1992. The amenity and environmental value of river corridors in Britain. In: Boon, P.J., P. Calow, G. (eds.), Petts, River Conservation and Management. Wiley, New-York, pp. 425-441.

Gruehn D., Roth M., 2010. Landscape preference study of agricultural landscapes in Germany. Tájökológiai Lapok Special Issue 2010: 67-78.

Gu X.P., Gu L.P., Zhou Y.B., Yin Y., Yu L.F., Cao M.Y., 2008. Quality evaluation of in-forest landscapes in Qipanshan scenic Area in Shenyang city. Journal of West China Forestry Science. 37(4): 49-55.

Huan G.Y. 2012. Studies on species composition and landscape aesthetics evaluation of urban forest in Beijing. D.Sc.thesis, Beijing forestry university, Beijing, China. $170 \mathrm{p}$.

Hull IV R.B., Buhyoff G.J., 1986. The scenic beauty temporal distribution method: an attempt to make scenic beauty assessments compatible with forest planning efforts. Forest Science. 32(2): 271-286.

Jia L.M., Li X.W., Hao X.F., Liu J.Z., 2007. Principle of tending techniques on recreational forest of Pinus tabulaeformis in Beijing Mountainous area by SBE method. Scientia Silvae Sinicae. 43(9): 144-149.

Kaplan R., Kaplan S., 1989. The experience of nature: a psychological perspective. Cambridge University Press, New York.

Kearney A.R., Bradley G.A., Petrich C. H., Kaplan R., Kaplan S., Simpson-Colebank D., 2008. Public perception as support for scenic quality regulation in a nationally treasured landscape. Landscape and Urban Planning. 87: 117-128. DOI: 10.1016/j.landurbplan.2008.05.005

Li J.Y., Yan H.W., Tang Q., Zhu Y., 2011. Relationship between in-forest scenic beauty and the plant community structure in Shenyang. Journal of Northwest Forestry University. 26(2): 212-219.

Lu Z.S., Yu G.B., Zhang Z.Q., 1985. The dynamics of the scenic forest of the Zijin Mountain and the management concerned. Journal of Nanjing Institute of Forestry. 3: $1-12$.

Lothian A., 1999. Landscape and the philosophy of aesthetics: is landscape quality inherent in the landscape or in the eye of the beholder? Landscape and Urban Planning. 44: 177-198. DOI: 10.1016/S0169-2046(99)00019-5

Marylise C., Hervé P., Gudrun B., 2013. Does human perception of wetland aesthetic and healthiness relate to ecological functioning? Journal of Environmental Management. 128: 1012-1022. DOI: 10.1016/ j.jenvman.2013.06.056

Millennium Ecosystem Assessment, 2005. Ecosystems and Human Well-being: Synthesis. Island Press Washington DC.

Niemelä J., Saarela S.R., Söderman T., Kopperoinen L., Yli-Pelkonen V., Väre S., 2010. Using the ecosystem services approach for better planning and conservation of urban green spaces: A Finland case study. Biodiversity and Conservation. 19: 3225-3243. DOI: 10.1007/ s10531-010-9888-8

Pâtru-Stupariu, I., Stupariu, M.S., Huzui, A., 2010. Mathematical models used for visual assessment of the landscape in situ - case study Sinaia Town, Forum Geografic. 9:133-138.

Raitz K., Dakhil M., 1988. Recreational choices and environmental preference. Annals of Tourism Research. 15: 357-370. DOI: 10.1016/0160-7383(88)90027-8

Ribe R.G., 2002. Is scenic beauty a proxy for acceptable management? The Influence of Environmental Attitudes on Landscape Perceptions. Environment and Behavior. 34 (6): 757-780. DOI: 10.1177/001391602237245

Ribe R.G., 2009. In-stand scenic beauty of variable retention harvests and mature forests in the U.S. Pacific Northwest: The effects of basal area, density, retention pattern and down wood. Journal of Environmental Management. 91: 245-260. DOI: 10.1016/j.jenvman.2009. 08.014

Roth M., Gruehn D., 2012. Visual landscape assessment for large areas - using GIS, internet surveys and statistical methodologies in participatory landscape planning for the Federal State of Mecklenburg-Western Pomerania, Germany. Latvian Acad. Sci. A: Humanit. Soc. Sci., 2012: 129-142.

Rudis V.A., Gramann J.H., Ruddell E. J., Westphal J. M., 1988. Forest inventory and management-based visual preference models of southern pine stands. Forest Science. 34(4): 846-863.

Silvennoinen H., Pukkala T., Tahvanainen L., 2002. Effect of cuttings on the scenic beauty of a tree stand. Scandinavian Journal of Forest Research. 17: 263-273. DOI: 
$10.1080 / 028275802753742936$

Tveit M., Ode Å., Fry G., 2006 . Key concepts in a framework for analyzing visual landscape character. Landscape Research. 31: 229-255. DOI: 10.1080/01426390 600783269

Tyrväinen L., Ojala A., Korpela K., Lanki T., Tsunetsugu Y., Kagawa T., 2014. The influence of urban green environments on stress relief measures: A field experiment. Journal of Environmental Psychology. 38: 1-9. DOI: 10.1016/j.jenvp.2013.12.005

Tzoulas K., Korpela K., Venn S., Yli-Pelkonen V., Kaźmierczak A., Niemelä J., James P., 2007. Promoting ecosystem and human health in urban areas using Green Infrastructure: A literature review. Landscape and Urban Planning. 81: 167-178. DOI: 10.1016/j.landurbplan. 2007.02.001

Van Den Berg A.E., Hartig T., Staats H., 2007. Preference for nature in urbanized societies: Stress, restoration, and the pursuit of sustainability. Journal of Social Issues, 63(1): 79-96. DOI: 10.1111/j.1540-4560.2007.00497.x

Vodak M., Roberts P., Wellman J.D., 1985. Scenic impacts of eastern hardwood management. Forest Science. 31(2): 289-301.

Wang J.L., Luo J.C., 2004. The synthetical assessment of quality of landscape Forest Community. Journal of Fujian College of Forestry. 24(4): 379-384.

Wascher D.M. (Ed.), 2000. The face of Europe. Policy perspectives for European landscapes. ECNC Technical Report Series. European Centre for Nature Conservation, Tilburg.

Williams K.J.H., Ford R.M., Bishop I.D., Loiterton D., Hickey J., 2007. Realism and selectivity in data-driven visualisations: a process for developing viewer-oriented landscape surrogates. Landscape and Urban Planning. 81: 213-224. DOI: 10.1016/j.landurbplan.2006.11.008

Yan J.F., Guan Q. W., Deng S.Q., Yu S.Q., Ma Y., 2009. Journal of Chinese Urban Forestry. 7(1): 12-14.

Yang X.X., Kang X., Du Z., Bao Y.J., 2012. SBE methodbased forest landscape aesthetic quality evaluation of Changbai Moutain. Journal of Northwest Agricultural and Forestry university (Nat. Sci. Ed.). 40(6): 86-90, 98.

Zhang R. 2003. Studies on the tending of scenic and recreational forest in west mountain, Beijing. M.Sc. thesis, Beijing forestry university, Beijing, China, $108 \mathrm{p}$.

Zhang Z.D. 2007. Study on community ecology of Platycladus orientalis-Robinia pseudoacacia and the impacts on in-forest landscape in Beijing scenic-recreational forest. M.Sc. thesis, Fujian Agriculture and forestry university, Fujian, China, 52p.

Zubelzu S., del Campo C. 2014. Assessment method for agricultural landscapes through the objective quantification of aesthetic attributes. International Journal of Environmental Research. 8(4): 1251-1260. 